DOI 10.15826/qr.2020.2.481

УДК 94(47).084.3

\title{
“DIFFICULT QUESTIONS” OF RUSSIAN HISTORY: OPINIONS AND FORECASTS ${ }^{* *}$
}

\author{
Alexander Chubariyan \\ State Academic University for the Humanities, \\ Institute of World History of the Russian Academy of Sciences, \\ Moscow, Russia
}

This article deals with the professional discussion about the so-called "difficult questions" of Russian history that involves historians and teachers in the now independent republics of the former Soviet Union and Eastern Block. Both academic publications and teaching books are used as primary sources for the study. In the first section, the author studies several problems connected with the origin of Russian statehood, the Varangian question, and civilizational characteristics of East Slavic nations. The second section is devoted to the Russian imperial past and especially to the discourse on colonialism, which is often used as an explanatory model for the imperial period by historians and textbook authors in some of the post-Soviet countries. The third section is concerned with the conception of the 1917 revolution. The author emphasizes the fact that the conception of a continuous revolutionary process (1917-1922) has yet to be accepted by Russian secondary schools. In this part, the author considers several other factors significant for understanding the revolutionary process including issues such as the origins of the First World War and the developmental level of the Russian Empire in the early twentieth century. In the fourth section, the article discusses the conception of the 1930s Soviet modernization along with negative opinions about the Soviet period given by scholars of different former Soviet republics. In the fifth section, the author briefly observes contemporary studies of culture and everyday life. It is concluded that the history of culture is not represented well in Russian school textbooks, and it is also found that the studies on everyday life are often lacking in depth. Discussing various "difficult questions" of Russian history, the author highlights controversial historical ideas and opinions, formulated in the post-Soviet countries during the last decades.

Keywords: history education; national history; Varangian question; Russian Empire; 1917 Russian Revolution; Soviet modernization.

\footnotetext{
* The article was written as part of the project 33.4122.2017 / PCH, supported by the Ministry of Science and Higher Education of the Russian Federation.

** Citation: Chubariyan, A. (2020). "Difficult questions" of Russian History: Opinions and Forecasts. In Quaestio Rossica. Vol. 8, № 2. P. 575-590. DOI 10.15826/qr.2020.2.481.

Цитирование: Chubariyan A. "Difficult questions" of Russian History: Opinions and Forecasts // Quaestio Rossica. Vol. 8. 2020. № 2. P. 575-590. DOI 10.15826/qr.2020.2.481.
}

(C) Chubariyan A., 2020

Quaestio Rossica • Vol. 8 • 2020 • № 2, p. 575-590 
Предметом исследования является профессиональная дискуссия историков и преподавателей истории в странах бывшего Советского Союза и Восточного блока по так называемым «трудным вопросам» российской истории. Автор привлекает современные научные публикации, затрагивающие такие вопросы, и учебные издания. Статья состоит из пяти разделов, каждый из которых соответствует одному из «трудных вопросов». В первом рассматривается состояние исследований по проблеме образования древнерусского государства, варяжскому вопросу и цивилизационным особенностям восточнославянских народов. Второй раздел посвящен проблеме имперского прошлого России и колониальному дискурсу как новой объяснительной модели, применяемой к имперскому периоду историками и авторами учебников в некоторых странах бывшего СССР. В третьей части, касаясь революционных событий 1917 г., автор отмечает, что выдвинутая несколько лет назад концепция единого революционного процесса (1917-1922) до сих пор не закрепилась в российской школе. Кратко рассмотрены другие проблемы, важные для понимания истории революции: истоки Первой мировой войны и уровень развития Российской империи в начале XX в. В четвертой части обсуждается концепция советской модернизации 1930-х гг. и рассматриваются негативные оценки советского периода истории в бывших союзных республиках. В пятой части дан краткий обзор проблем, связанных с исследованием и репрезентацией истории повседневности и культуры. Сделан вывод, что история культуры недостаточно представлена в российских школьных учебниках, а исследования по истории повседневности нередко имеют поверхностный характер. Обсуждая различные «трудные вопросы» российской истории, автор указывает на противоречивые исторические гипотезы и мнения, сформировавшиеся в последние десятилетия на постсоветском пространстве.

Ключевые слова: историческое образование; национальная история; варяжский вопрос; Российская империя; революция 1917 г.; советская модернизация.

In recent years, the term "difficult questions of history" has been at the forefront of Russian discussions on the problem of historical education. The emergence of the term immediately raised some doubts and objections, as a logical question arose: "What do the so-called 'difficult questions' mean in history?"

The concept of "difficult questions" was formed in 2014 as a result of radical changes in the study and teaching of history in secondary schools. The changes led to a certain variability in the sphere, and dozens of textbooks for high school appeared then. At the same time, the Russian scientific and educational community as well as the media started discussions about revising the previously formed views on many events in the history of our country from ancient times to the present.

History teachers found it difficult to navigate in such a difficult situation. A typical Russian teacher, having their own priorities, preferences, and 
their own attitude to certain historical events, also has to convey the modern point of view of the national historical science to their students in the process of teaching. It is not surprising that it was the teachers who made the list of "difficult questions" of Russian history, which caused disputes among scholars and specialists in world and national history. In response to these requests, 20 methodological brochures were created, revealing current views on "difficult questions". At the same time, a number of research projects were initiated. The task was to rethink or clarify and correct the previous, seemingly well-established views on events in Russian history. This was also facilitated by the study of new documents and other evidence which were introduced for scientific use, as well as the process of revising previous theories and concepts in several countries (Poland, Ukraine, the Baltic States, etc.), which were imposed by politics.

\section{The origins of Kievan Rus'}

Many historical issues are connected with the origins of Kievan Rus'. Earlier, the confrontation between "Normanists" and "anti-Normanists" in understanding Rurik and the Scandinavian's role in the formation of Kievan Rus' was the main point of discussion. The discussion on these issues that took place in Soviet historiography ended up by the beginning of the 1980s with the formation of an official position, which was reflected in the works of B. A. Rybakov [Рыбаков] on the one hand, and A. A. Zimin [Зимин] on the other. Soviet historians agreed that Rurik came with his men not to "empty space", but to a territory where people already had their own economy and developed social structures. Soviet scholars postulated that the Scandinavians did not play a crucial role in the formation of the state in this territory. However, most scholars held that Scandinavian traders and warriors exercised considerable influence over Slavic tribes of Eastern Europe [Славяне и скандинавы].

In the 1980s, Soviet historians did not deny that the Varangians could possibly originate in Scandinavia, and even Scandinavian roots for the name Rus' were found in the last years of the Soviet period [Мельникова, Петрухин]. It should be noted that there was a revival of the interest in the Varangian question in the 2000s. At this new stage, participants in the debate are concerned with the ethnic origins of the Varangians, their cultural influence on East Slavic tribes, and the interaction between Slavic and Scandinavian political traditions [Сахаров; Мельникова, 2011; Мельникова, 2017].

Soviet scholars held that Kievan Rus' created the basis for the formation of Russian, Ukrainian and Belarusian civilizational entities [Пашуто, Флоря, Хорошкевич; Флоря]. However, Kiev has recently developed its own concept of the history of that period, which is based on the idea of only Ukrainian statehood, while denying the value of the Russian component [Гісем; Власов; Струкевич]. Given that no new documentary evidence has appeared, we can assume the presence of political bias in this interpretation. It is worth mentioning that the "new trends" in the Ukraine do not come from classical academic scientists [История Украины], but mainly from 
journalists, political scientists, and so on. Nevertheless, it is obvious that we should give a more detailed and documented justification of the Kiev Rus' development history in educational literature, pay more attention to the formation of Ukrainian nation and the elements of statehood [Россия и Украина на перекрестках истории].

\section{Russian Empire: the issues of evolution}

The problem of formation and evolution of the Russian Empire is also considered among these "difficult questions". In Soviet historiography, there were controversial views on the history of the territories of the Caucasus (Armenia and Georgia) and Central Asia becoming part of the Russian Empire. The official idea of the authorities about the so-called "voluntary entry" of these peoples and territories into Russia was often rejected and debated by local national elites [Невская, Кондрашева]. In the 1950s and 1960s, the "lesser evil theory" was even put forward. It stated that, for example, for Armenia and Georgia, their inclusion in Russia was the lesser evil compared to joining Turkey or Persia [Война и ислам на Ceверном Кавказе]. The topic of any negative aspects of "accession of these territories" to the Russian Empire was not raised at all. The incorporation of the Ukraine into Russia in the $17^{\text {th }}$ century as a result of the initiative of Bogdan Khmelnitsky was seamlessly included in this scheme. However, when the former Soviet republics became independent states after the collapse of the Soviet Union in 1991, they began to build their own history and look for their own identity.

In contrast to the previous generally accepted concept, the period when they were parts of the Russian Empire was characterized as "colonial". This definition was included in the history textbooks of schools, and in the programs of higher education institutions. Some scientific papers explaining this process of their development were published and various characteristics of the "colonial" period were presented: in some works, the focus was made on seizure and oppression, suppression of independence and culture [Кениньш; Kurlovičs, Tomašūns; Курлович, Томашун; Рахимов; Чоротегин, Омурбеков; Омурбеков, Чоротегин]. Other works attempted to explain the term "colonial period" as taking account of the differences between the traditional understanding of "colonies" (mainly overseas territories) and what happened in the outskirts of the former Imperial Russia, with particular attention paid to economic and cultural development, and the establishment of political organizations ${ }^{1}$.

The problem of the Russian Empire's formation concerns the development of Russian Siberia and the Far East, the annexation of the Caucasus and other areas of the Volga region. These issues remain the

${ }^{1}$ See, for example, the history textbooks edited by the academician of the national Academy of Sciences of Armenia V. Barkhudaryan [История Армении для 8-го класса, 2005; История Армении для 8-го класса, 2007; История Армении в контексте мировой истории для 9-го класса]. 
subject of discussion in the scientific and educational societies of modern Russia [История Сибири].

In all regions and republics of Russia, schools mention the so-called "regional component" (local specificity), which actualizes the problem of modern scientific assessment of the history and development of the regions, including those within the Russian Empire [История Оренбургского края; История Крыма; История Сибири; Россия - Башкортостан; История Саратовского Поволжья]. This task requires an interdisciplinary approach and the use of a comparative method - comparing the processes that took place in the Russian Empire with similar examples in the Persian, Ottoman, and British empires.

The problem of the Empire inevitably leads to new approaches in the study of colonialism in general and in a specific historical context, as well as to the study of imperial attitudes in the metropolises themselves.

At meetings with colleagues from post-Soviet countries, Russian historians drew attention to the vulnerability of transferring the general concept and practice of colonialism to characterize the position of individual countries within the Russian Empire. Taking the actual practice into account, we can expect that in the post-Soviet countries the research of "Russian colonialism" will become more popular, and in this situation the study of Russian history (the Imperial period) will acquire a special meaning (the international school of young scientists and historians has ended in Moscow...).

In practice, this may lead to new approaches in the study of the "Treaty of Georgievsk", which determined the accession of Georgia to Russia, in the study of the processes that took place in Central Asia (the uprising in Turkestan in 1916, etc.) [Восстание 1916 года в Туркестане]. In 2016, Kyrgyzstan's increased attention to the history of the 1916 uprising indicated a growing trend [Российская газета - Неделя: Киргизия].

The problems related to the Ukraine's accession to Russia remain important. In the early 1990s, after Ukraine gained independence, Ukrainian historians began to formulate new approaches to the events of the $17^{\text {th }}-18^{\text {th }}$ centuries, different from traditional Soviet historiography. Recently, a number of works devoted to Ivan Mazepa were published, in which special attention was paid to the problem of the Ukraine's accession to Russia [3 епістолярної спадщини гетьмана Івана Мазепи; Листи Івана Мазепи; Мазепина книга; Ковалевська; Павленко; Таїрова-Яковлева]. In accordance with new trends, the most radical authors in Kiev began to use the term "forcible absorption" of Ukrainian lands by Russia.

Russian historical science has faced the need to update the argumentation when describing the complex process of interaction between Russia and the Ukrainian Cossacks and the State. This is the subject of joint research of Russian and Ukrainian historians [История Украины; Данилевский, Таирова-Яковлева, Шубин, Мироненко], which uses modern and documented approaches that appeal to the process of the Ukraine's accession to Russia in the $17^{\text {th }}$ century. 
The main task is to avoid excessive politicization, taking new documents and the study of various interdependent factors into account; to reveal the process of formation of the Russian Empire, the development of the lands of the former Tsarist Empire. A balanced and unbiased assessment of the policy of Russification of national borders is needed, as well as a sober understanding of the many advantages these regions received from joining the Russian Empire in terms of economic and cultural growth, the development of political institutions and civil society, and the preservation of border security from external military threats.

\section{Revolution and Civil War: A New Axiology}

One of the most controversial topics is the history of the Russian Revolution of 1917 and the Civil War.

It seemed that this issue was finally resolved in the preparation of the historical and cultural standard in 2019. Then, by analogy with the French Revolution of the $18^{\text {th }}$ century, the Russian revolution was considered as a process, the stages of which were the February and October revolutions, and the Civil War. Thus, the Russian revolution covered the period of 19171922 [Концепция нового учебно-методического комплекса по отечественной истории]. This chronology was determined by the emergence of new data, as well as new approaches to the interpretation of the history of the Russian revolution, including the important position about "own truth" among the Reds and the Whites.

My communication with history teachers, however, shows that obsolete chronology and assessments are still often used, and the new concept of the Russian revolution and the Civil War needs a deeper documentary and theoretical justification, as well as accessible presentation forms. A new "reading" of the history of the Russian revolution was announced in the year of the centenary of the revolution. Since 1991, the ROSSPEN publishing house, in cooperation with Russian and foreign scientific centers has been implementing a project to publish documents of Russian political parties from the late $19^{\text {th }}$ - early $20^{\text {th }}$ centuries, in the series "Political Parties of Russia. The end of the $19^{\text {th }}$ - the first third of the $20^{\text {th }}$ century. Documentary Heritage." 2

The complexity of the situation is that a change in concept led to the disappearance of a significant historical heritage, because many hundreds, or maybe thousands of collections of documents, scientific and educational

\footnotetext{
${ }^{2}$ In 2017, on the 100th anniversary of the Revolution in Russia, scholars released many monographs, e. g. [1917 г. Вокруг Зимнего; Аксютин, Гердт; Медушевский; Хандорин; Шубин, 2017a, 20176], collections of articles [Россия в 1917 году; Российская революция 1917 года и ее место в истории XX века] collections of documents [Революция 1917 года глазами современников; А. Ф. Керенский: pro et contra; Л. Д. Троцкий: pro et contra], memoirs of contemporaries of the events [Изгоев; Троцкий, 2017a, 20176; Революция глазами современников; Штейнберг; «Свет во тьме...»; Сомов], chronicles [1917 год. Петроград. Москва. Богородск; Гагкуев, Репников], biographies of the leaders of the Revolution of 1917 [Колоницкий; Данилкин]; also, works by Western historians were translated and published [Историческая неизбежность?; Скочпол].
} 
works contained "evidence" of the old concept of the history of the Russian revolution. The task is to take the necessary documents and memoirs from these previous works and collections and correlate them with the arguments about a new interpretation and a "new chronology" of the history of the Russian revolution and the Civil War. It is also necessary to answer the discussion questions that arose in connection with the scientific substantiation of the $100^{\text {th }}$ anniversary of the Great Russian Revolution.

In Soviet times, the idea prevailed that Russia in 1917 and during the war was one of the most backward countries, and that in this situation only the October Revolution opened the way for Russia to recover. Now these estimates have changed dramatically: it is argued that by 1913 Russia was among the most advanced countries in terms of economic indicators [Mapкевич, Харрисон; Петров, Журавлев, Бахтурина]. It is clear that further scientific studies of the real state of the Russian economy, as well as its role and place in world economic development, are required.

In the past, the question of the role of the First World War in the fate of Russia and in the preconditions of the Russian revolution was actually removed from the sphere of scientific circulation. To date, serious scientific research has been published on the origin, course and history of the First World War [Война и общество в XX в.; Первая мировая война на почтовых открытках; Петров, Павлов; Россия в системе международных отношений; Россия и Первая мировая война]. But it seems that this is only the beginning of new studies of the First World War and the consequences of this war for Russia.

\section{The Soviet period in the history of Russia: the empire "vice versa"}

The assessment of the Russian revolution is inseparable from the general understanding of the place of the "Soviet period" in the life and development of Russian history. It is known that from the beginning of the 1990s, extremely negative characteristics of the Soviet era were given in our historical literature and journalism. However, there are differences in emphasis, for example, the period 1920-1930 and the postwar years [Бахтурина]. This question arose quite sharply in preparing the cultural-historical standard for high school. In the course of historical discussions, the idea came to call the period of the 1930s "the Soviet version of modernization," which makes it possible to include in this concept all the difficulties of creating a large industry, collectivizing agriculture with tragic consequences, mass repressions, but at the same time successes in industrialization, science, culture, education, etc. It seems that the comprehensive justification of our assessments of the Soviet period is one of the important tasks of modern Russian historiography and political science.

It cannot be solved without the combined efforts of specialists from different disciplines: historians, economists, legal scholars, political scientists, sociologists etc. Studies are complicated by the fact that in the public consciousness there are significant differences in the perception of the relatively recent historical past. The difficulties are compounded by the 
real contradictions of the Soviet era: the proximity of negative episodes of history with obvious achievements and successes. Russian researchers are faced with the task of developing new criteria and methods for analyzing such a complex and controversial phenomenon as Soviet society and the Soviet system.

When choosing a research topic, a new generation of scientific personnel is not particularly interested in problems of the Soviet period. Apparently, this is due to distrust of previously published collections of documents and concerns about the correctness of the results due to the apparent uncertainty and inconsistency of the estimates of the Soviet period as a whole and on its merits.

The problem of assessing the Soviet period has not only a Russian, but also an international context. All countries of the post-Soviet space have passed the "Soviet period", and the attitude of different states to it varies. The Baltic countries are ready to erase the Soviet period from their history, declaring it an occupation by Moscow, although these countries were led by their own figures. The Baltic countries ignore the obvious fact that during the years of Soviet power they received strong financial and economic support, which contributed to the successful development of culture, science and education.

A much more complex perception of the Soviet era exists in the CIS countries. In the early 1990s, a number of CIS countries put forward the idea of continuing the colonial era of the Russian Empire in the Soviet Union [Советские нации]. But this trend has not been developed: it is too obvious that it contradicted the realities of that time. The Soviet republics of Central Asia and the Caucasus during the period of Soviet power had significant privileges, and the local elite and national nomenclature were at the head of the republics. The process of gaining independence was completely led by national leaders [Бахтурина].

Held in 2017-2018, the centennial of the Russian revolution was simultaneously accompanied by the celebrations of the centenary of statehood in Belarus, Kazakhstan, Armenia and other post-Soviet countries. The same anniversary was celebrated in Tatarstan, Bashkortostan, etc.

In the Ukraine, the events of 1918-1919 attract special attention today. In numerous works of Ukrainian historians, the short-term period of the reign of the Ukrainian Central Rada is considered as a certain standard of Ukrainian statehood [Литвин; Хміль]. Meanwhile, it is known that the Ukraine during the Central Rada was actually under the German protectorate. This period is depicted as a time of "deliverance" from Moscow and from the Moscow Bolsheviks, although there was a sharp struggle in the Ukraine itself, including with the participation of the Ukrainian Bolsheviks [Михутина; Солдатенко].

\section{History of everyday life and culture}

There are a number of topics that did not fall into the category of difficult ones, but which should be specially mentioned. Modern history textbooks and educational programs have little space, for example, for the 
history of everyday life, which today is at the center of many international studies. It seems that in the domestic scientific tradition, methodological approaches and criteria for historical tools to include everyday history in the general research scheme have not been developed. The sections that tell about everyday life, which are now present in a number of scientific works and in educational programs, look rather simplified and superficial.

Equally important is the lack of attention paid to the problems of cultural history. The deficit of efforts in the coverage of culture in textbooks persists from Soviet times. As a rule, it all came down to a simple enumeration of cultural figures in various historical periods. Meanwhile, it is very important to explain the importance of culture in the history of mankind as one of the main aspects of spiritual life, thus, special attention should be paid to the role and place of the Russian culture, including Soviet.

The presented notes do not consider the content of many other topics and problems in the course of national history in school and university educational programs, which need additional substantiation and development. I have cited a number of examples of the so-called "difficult questions" to draw attention to the interconnection and interinfluence of education and science, and to establish how the needs of education, including in high school, can stimulate basic scientific research.

\section{Список литературы}

1917 г. Вокруг Зимнего / сост. Ю. З. Кантор. М. : РОССПЭН, 2017. 247 с.

1917 год. Петроград. Москва. Богородск : Хроника событий / авт.-сост. Е. Маслов. Черноголовка : Богородский печатник, 2017. 122 с.

А. Ф. Керенский: pro et contra : антология / сост., вступ. ст., коммент. А. Б. Николаева. СПб. : РХГА, 2016. 768 с.

Аксютин Ю. В., Гердт Н. Е. Русская интеллигенция и революция 1917 года: в хаосе событий и в смятении чувств. М. : РОССПЭН, 2017. 703 с.

Бахтурина А. Ю. Советская национальная политика // ЭНОЖ «История» : [сайт]. Трудные вопросы истории России. URL: https://history.jes.su/s207987840004708-7-1/ (дата обращения: 22.04.2020). DOI 10.18254/S2079878404708-7.

Власов B. С. Історія України : підруч. для 8-го кл. загально-освіт. навч. закл. Київ : Генеза, 2016. 256 c.

Война и ислам на Северном Кавказе ХІХ-XX вв. М. : Ин-т рос. истории РАН, 2000. $54 \mathrm{c}$.

Война и общество в XX в. : в 3 кн. М. : Наука, 2008. Кн. 1. Война и общество накануне и в период Первой мировой войны. $611 \mathrm{c}$.

Восстание 1916 года в Туркестане: документальные свидетельства общей трагедии : сб. док. и материалов. М. : Марджани, 2016. 468 с.

Гісем O. В. Історія України : підручник для 7 кл. загальноосвіт. навч. закл. Тернопіль : Навчальна книга - Богдан, 2015. 272 с.

Гагкуев Р. Г., Репников А. В. Великая Революция 1917 года. Иллюстрированная летопись. М. : ЭКСМО : Яуза, 2017. 224 с.

Данилевский И. Н., Таирова-Яковлева Т. Г., Шубин А. В., Мироненко В. И. История Украины. СПб. : Алетейя, 2015. 508 с.

Данилкин Л. А. Ленин : Пантократор солнечных пылинок. М. : Молодая гвардия, 2017. $784 \mathrm{c}$.

3 епістолярної спадщини гетьмана Івана Мазепи. Київ : Ін-т історії України НАН України, 1996. 191 с. 
Зимин A. A. О методике изучения древнерусского летописания // Изв. Акад. наук СССР. Сер. Лит. и яз. Т. 33. 1974. № 5. С. 454-464.

Изгоев А. С. Рожденное в революционной смуте. М. : Изд. дом «Дело» РАНХиГС, 2017. $600 \mathrm{c}$.

Историческая неизбежность? Ключевые события русской революции / под ред. Т. Брентона. М. : Альпина нонфикшн, 2017. 414 с.

История Армении в контексте мировой истории для 9-го класса / под ред. В. Бархударяна. Ереван : Зангак-97, 2001.

История Армении для 8-го класса / под ред. В. Бархударяна. Ереван : Луйс, 2005.

История Армении для 8-го класса / под ред. В. Бархударяна. Ереван : Макмиллан - Армения, 2007.

История Крыма // ЭНОЖ «История» : [сайт]. URL: https://history.jes.su/ issue.2017.2.4.e12/ (дата обращения: 20.12.2019).

История Оренбургского края // ЭНОЖ «История» : [сайт]. URL: https://history.jes. su/issue.2017.3.9.e13/ (дата обращения: 20.12.2019).

История Саратовского Поволжья // ЭНОЖ «История» : [сайт]. URL: https:/history. jes.su/issue.2015.3.9.e4/ (дата обращения: 20.12.2019).

История Сибири // ЭНОЖ «История» : [сайт]. URL: https://history.jes.su/ issue.2016.4.10.e11/ (дата обращения: 20.12.2019).

История Украины : науч.-популяр. очерки / под ред. В. А. Смолия. М. : ОЛМА Медиа Групп, 2008. 1070 с.

Кениньи И. История Латвии : учебник для 8-9-х классов. Рига : Zvaigzne, 1990. $223 \mathrm{c}$.

Ковалевська О. Іконографія Івана Мазепи в образотворчому мистецтві XX - початку XXI ст. Київ : Темпора, 2013. 420 с.

Колоничкий Б. И. «Товарищ Керенский»: антимонархическая революция и формирование культа «вождя народа» (март - июнь 1917 года). М. : Новое лит. обозрение, 2017. 520 с.

Концепция нового учебно-методического комплекса по отечественной истории // Городской методический центр : [сайт]. URL: https://mosmetod.ru/files/metod/ srednyaya_starshaya/istor/Koncepcia_final.pdf (дата обращения: 20.12.2019).

Курлович Г., Томашун А. История Латвии : для основной школы. Рига : Zvaigzne ABC, 2002. $295 \mathrm{c}$.

Л. Д. Троцкий: pro et contra : антология / сост., вступ. ст., коммент. А. В. Резника. СПб. : РХГА, 2016. 864 с.

Листи Івана Мазепи : в 2 т. / упорядн. та авт. передм. В. Станіславський. Київ : Інститут історії України НАНУ, 2002, 2010. Т. 1. 1687-1691. 480 с. Т. 2. 1691-1700. 752 с.

Литвин С. Суд історії: Симон Петлюра і петлюріана. Київ : Вид-во ім. Олени Теліги, 2001. $640 \mathrm{c}$.

Мазепина книга / упор. та вступна стаття І. Ситого. Чернігів : ЦНТЕІ, 2005. 524 с. Маркевич А., Харрисон М. Первая мировая война, Гражданская война и восстановление: национальный доход России в 1913-1928 гг. М. : Мысль, 2013. 111 с.

Медушевский А. Н. Политическая история русской революции: нормы, институты, формы социальной мобилизации в XX веке. М. ; СПб. : Центр гуманитар. инициатив, 2017. $656 \mathrm{c}$.

Мельникова $E$. A. Ряд в Сказании о призвании варягов и его европейские и скандинавские параллели // Мельникова Е. А. Древняя Русь и Скандинавия : избр. тр. М. : Рус. фонд содействия образованию и науке, 2011. С. 249-256.

Мельникова Е. А. Норманнская проблема // Древняя Русь в средневековом мире : энциклопедия. М. : Ладомир, 2017. С. 560-561.

Мельникова E. А., Петрухин В. Я. Название «Русь» в этнокультурной истории Древнерусского государства // Вопр. истории. 1989. № 8. С. 24-38.

Михутина И. В. Украинский Брестский мир. Путь выхода России из Первой мировой войны и анатомия конфликта между Совнаркомом РСФСР и правительством Украинской Центральной рады. М. : Европа, 2007. 288 с. 
Невская Т. А., Кондрашева А. С. Власть и реформы на Северном Кавказе (конец XVIII - начало XX вв.). Ставрополь : Изд-во СевКавГТУ, 2011.91 с.

Омурбеков Т. Н., Чоротегин Т. К. История Кыргызстана (XIX в. - 1917 г.) : учебник для 8 кл. средних школ. Бишкек : Бийиктик, 2005. 192 с.

Павленко С. Іван Мазепа як будівничий української культури. Київ : КиєвоМогилянська акад., 2005. 304 с.

Пашуто В. Т., Флоря Б. Н., Хорошкевич А. Л. Древнерусское наследие и исторические судьбы восточного славянства. М. : Наука, 1982. 264 с.

Первая мировая война на почтовых открытках : в 4 кн. Киров : Крепостновъ, 2014. 1692 c.

Петров Ю. А., Журавлев С. В., Бахтурина А. Ю. Причины, последствия и оценка падения монархии в России, Революции 1917 г., прихода к власти большевиков и их победы в Гражданской войне // ЭНОЖ «История» : [сайт]. Трудные вопросы истории России. URL: https://history.jes.su/s207987840001282-9-1/ (дата обращения: 22.04.2020). DOI 10.18254/S207987840001282-9.

Петров Ю. А., Павлов Д. Б. Первая мировая война: кто виноват? : (Историографический этюд) // Рос. ист. 2014. № 5. С. 3-13.

Рахимов Ж. История Узбекистана (вторая половина XIX в. - начало XX в.) : учебник для 9-го класса. Ташкент : Узбекистон, 2001. 334 с.

Революция 1917 года глазами современников : в 3 т. М. : РОССПЭН, 2017. 1608 с.

Революция глазами современников / сост. Т. Ф. Прокопов. М. : АСТ, 2017. 480 с.

Российская газета - Неделя : Киргизия. № 6975. 2016. 19 мая // Рос. газ. : [сайт]. URL: https://rg.ru/gazeta/nedelya-aziya/2016/05/19.html (дата обращения: 20.12.2019).

Российская революция 1917 года и ее место в истории XX века / под ред. А. В. Торкунова, А. О. Чубарьяна. М. : Весь мир, 2018. 352 с.

Россия - Башкортостан: общность исторических судеб // ЭНОЖ «История» : [сайт]. URL: https://history.jes.su/issue.2015.3.9.e5/ (дата обращения: 20.12.2019).

Россия в 1917 году : энциклопедия / отв. ред. А. К. Сорокин. М. : РОССПЭН, 2017. 1095 c.

Россия в системе международных отношений накануне и в годы Первой мировой войны : в 3 т. М. : Междунар. отношения, 2019. 1368 с.

Россия и Первая мировая война: экономические проблемы, общественные настроения, международные отношения. М. : Ин-т рос. истории РАН, 2014. 416 с.

Россия и Украина на перекрестках истории : пособие для учителей истории. М. : ОЛМА Медиа Групп, 2012. 320 с.

Рыбаков Б. А. Киевская Русь и русские княжества XII-XIII вв. М. : Наука, 1982. $592 \mathrm{c}$.

Сахаров A. Н. Рюрик, варяги и судьбы российской государственности // Сборник Русского исторического общества. 2003. № 8 (156). С. 9-17.

«Свет во тьме...». В борьбе за Россию. 1917-1922. М. : Посев, 2017. 305 с.

Скочпол T. Государства и социальные революции: сравнительный анализ Франции, России и Китая. М. : Изд-во Ин-та Гайдара, 2017. 550 с.

Славяне и скандинавы / под ред. Е. А. Мельниковой. М. : Прогресс, 1986. 416 с.

Советские нации и национальная политика в 1920-1950-е годы : материалы VI

Междунар. науч. конф., Киев, 10-12 октября 2013 г. М. : Полит. энцикл. : Фонд «Президентский центр Б. Н. Ельцина», 2014. 686 с.

Солдатенко В. Ф. Українська революція. Історичний нарис. Київ : Либідь, 1999. $976 \mathrm{c}$.

Сомов К. А. Дневник. 1917-1923. М. : Дмитрий Сечин, 2017. 928 с.

Струкевич O. К. Історія України : підруч. для 9 кл. загальноосвіт. навч. закл. Київ : Грамота, 2017. $240 \mathrm{c.}$

Таӥрова-Яковлева Т. Г. Іван Мазепа і Російська імперія. Історія «зради». Київ : Кліо, 2013. 403 с.

Троикий Л. Д. История русской революции. Октябрьская революция. М. : Вече, 2017a. 416 c. 
Трочкий Л. Д. История русской революции. Февральская революция. М. : Вече, 2017б. 448 c.

Флоря Б. Н. О некоторых особенностях развития этнического самосознания восточных славян в эпоху Средневековья - раннего Нового времени // Россия - Украина: история взаимоотношений. М. : Школа «Языки рус. культуры», 1997. С. 9-27.

Хандорин В. Г. Национальная идея и адмирал Колчак. М. : Рус. фонд содействия образованию и науке, 2017. 624 с.

Хміль I. В. На шляху відродження української державності : (Український національний конгрес-з’їзд 6-8 квітня 1917 р.). Київ : Ін-т історії України НАН України, 1994. 62 с.

Чоротегин Т. К., Омурбеков Т. Н. История Кыргызстана (IX-XVIII вв.) : учебник для 7 кл. средних школ. Бишкек : Бийиктик, 2005. 184 с.

Штейнберг И. 3. Нравственный лик революции. М. : Кучково поле, 2017. 416 с.

Шубин А. В. Великая российская революция : 10 вопросов. М. : История, 2017а. 46 с.

Шубин А. В. Старт Страны Советов. Революция. Октябрь 1917 - март 1918. СПб. : Питер, 20176. 448 c.

Kurlovičs G., Tomašūns A. Latvijas vēsture vidusskolai. 1. daļa. Eksperimentāla mācību grāmata. Rīga : Zvaigzne ABC, 1999. 255 lpp.

\section{References}

Aksyutin, Yu. V., Gerdt, N. E. (2017). Russkaya intelligentsiya i revolyutsiya 1917 goda: $v$ khaose sobytii $i$ v smyatenii chuvstv [The Russian Intelligentsia and the 1917 Revolution: In the Chaos of Events and in the Confusion of Feelings]. Moscow, ROSSPEN. 703 p.

Bakhturina, A. Yu. (2018). Sovetskaya natsional'naya politika [Soviet National Policy]. In Elektronnyi nauchno-obrazovatel'nyi zhurnal "Istoriya" [website]. Trudnye voprosy istorii Rossii. URL: https://history.jes.su/s207987840004708-7-1/ (mode of access: 22.04.2020). DOI 10.18254/S2079878404708-7.

Barkhudaryan, V. (Ed.). (2001). Istoriya Armenii v kontekste mirovoi istorii dlya 9-go klassa [History of Armenia in the Context of World History for the $9^{\text {th }}$ Grade]. Erevan, Zangak-97.

Barkhudaryan, V. (Ed.). (2005). Istoriya Armenii dlya 8-go klassa [History of Armenia for the $8^{\text {th }}$ Grade]. Erevan, Luis, 2005.

Barkhudaryan, V. (Ed.). (2007). Istoriya Armenii dlya 8-go klassa [History of Armenia for the $8^{\text {th }}$ Grade]. Erevan, Makmillan - Armeniya.

Brenton, T. (Ed.). (2017). Istoricheskaya neizbezhnost'? Klyuchevye sobytiya russkoi revolyutsii [Historically Inevitable? Turning Points of the Russian Revolution]. Moscow, Al'pina nonfikshn. 414 p.

Chorotegin, T. K., Omurbekov, T. N. (2005). Istoriya Kyrgyzstana (IX-XVIII vv.). Uchebnik dlya 7 klassov srednikh shkol [History of Kyrgyzstan $\left(9^{\text {th }}-18^{\text {th }}\right.$ Centuries). Textbook for $7^{\text {th }}$ Grade High Schools]. Bishkek, Biiiktik. 184 p.

Danilevskii, I. N., Tairova-Yakovleva, T. G., Shubin, A. V., Mironenko, V. I. (2015). Istoriya Ukrainy [History of Ukraine]. St Petersburg, Aleteiya. 508 p.

Danilkin, L. A. (2017). Lenin. Pantokrator solnechnykh pylinok [Lenin. Pantocrator of the Solar Dust]. Moscow, Molodaya gvardiya. $784 \mathrm{p}$.

Florya, B. N. (1997). O nekotorykh osobennostyakh razvitiya etnicheskogo samosoznaniya vostochnykh slavyan v epokhu Srednevekov'ya - Rannego Novogo vremeni [On Some Features of Development of Ethnic Identity of the Eastern Slavs in the Middle Ages - Early Modern Times]. In Rossiya - Ukraina: istoriya vzaimootnoshenii. Moscow, Shkola "Yazyki russkoi kul'tury", pp. 9-27.

Gagkuev, R. G., Repnikov, A. V. (2017). Velikaya Revolyutsiya 1917 goda. Illyustrirovannaya letopis' [The Great Revolution of 1917. Illustrated Chronicle]. Moscow, EKSMO, Yauza. 224 p.

Gisem, O. V. (2015). Istoriya Ukraïni. Pidruchnik dlya 7 klasiv zagal'noosvitnikh navchal'nikh zakladiv [History of Ukraine. $7^{\text {th }}$ Grade Textbook]. Ternopil', Navchal'na kniga - Bogdan. 272 p. 
Istoriya Kryma [History of Crimea]. In Elektronnyi nauchno-obrazovatel'nyi zhurnal "Istoriya" [website]. URL: https://history.jes.su/issue.2017.2.4.e12/ (mode of access: 20.12.2019).

Istoriya Orenburgskogo kraya [History of Orenburg Region]. In Elektronnyi nauchno-obrazovatel'nyi zhurnal "Istoriya" [website]. URL: https://history.jes.su/ issue.2017.3.9.e13/ (mode of access: 20.12.2019).

Istoriya Saratovskogo Povolzh'ya [History of the Saratov Volga]. In Elektronnyi nauchno-obrazovatel'nyi zhurnal "Istoriya" [website]. URL: https:/history.jes.su/ issue.2015.3.9.e4/ (mode of access: 20.12.2019).

Istoriya Sibiri [History of Siberia]. In Elektronnyi nauchno-obrazovatel'nyi zhurnal "Istoriya" [website]. URL: https://history.jes.su/issue.2016.4.10.e11/ (mode of access: 20.12.2019).

Izgoev, A. S. (2017). Rozhdennoe v revolyutsionnoi smute [Born in Revolutionary Turmoil]. Moscow, Izdatel'skii dom "Delo" Rossiiskoi akademii narodnogo khozyaistva i gosudarstvennoi sluzhby pri Prezidente Rossiiskoi Federatsii. 600 p.

Kantor, Yu. Z. (Ed.). (2017). 1917 g. Vokrug Zimnego [1917. Around the Winter Palace]. Moscow, ROSSPEN. 247 p.

Kenin'sh, I. (1990). Istoriya Latvii. Uchebnik dlya 8-9-kh klassov [History of Latvia. Textbook for Grades 8-9]. Riga, Zvaigzne. 223 p.

Khandorin, V. G. (2017). Natsional'naya ideya $i$ admiral Kolchak [National Idea and Admiral Kolchak]. Moscow, Russkii fond sodeistviya obrazovaniyu i nauke. 624 p.

Khmil', I. V. (1994). Na shlyakhu vidrodzhennya ukraïns'koï derzhavnosti. (Ukraïns 'kii natsional'nii kongres-z'izd 6-8 kvitnya 1917 roku) [Towards a Revival of Ukrainian Statehood. (Ukrainian National Congress-Congress April 6-8, 1917)]. Kiev, Institut istorii Ukraïny Natsional'noi akademii nauk Ukraïny. 62 p.

Kolonitskii, B. I. (2017). "Tovarishch Kerenskii": antimonarkhicheskaya revolyutsiya i formirovanie kul 'ta "vozhdya naroda" (mart - iyun' 1917 goda) [“Comrade Kerensky": the anti-Monarchist Revolution and the Formation of the Cult of the "Leader of the People"]. Moscow, Novoe literaturnoe obozrenie. 520 p.

Kontseptsiya novogo uchebno-metodicheskogo kompleksa po otechestvennoi istorii [The Concept of a New Teaching Module on National History]. In Gorodskoi metodicheskii tsentr [website]. URL: https://mosmetod.ru/files/metod/srednyaya_starshaya/istor/ Koncepcia_final.pdf (mode of access: 20.12.2019).

Kovalevs'ka, O. (2013). Ikonografiya Ivana Mazepi v obrazotvorchomu mistetstvi $X X-$ pochatku XXI st. [The Iconography of Ivan Mazepa in the Fine Arts of $20^{\text {th }}-$ Early of $21^{\text {st }}$ Centuries]. Kiev, Tempora. 420 p.

Kurlovičs, G., Tomašūns, A. (1999). Latvijas vēsture vidusskolai. 1. dalı. Eksperimentāla mācību grāmata. Rīga, Zvaigzne ABC. 255 lpp.

Kurlovičs, G., Tomašūns, A. (2002). Istoriya Latvii Dlya osnovnoi shkoly [History of Latvia. For Secondary School]. Riga, Zvaigzne ABC. 295 p.

Litvin, S. (2001). Sud istorii: Simon Petlyura i petlyuriana [The Court of History: Simon Petliura and Petliurian]. Kiev, Vidavnitstvo imeni Oleni Teligi. 640 p.

Markevich, A., Harrison, M. (2013). Pervaya mirovaya voina, Grazhdanskaya voina $i$ vosstanovlenie: natsional'nyi dokhod Rossii v 1913-1928 gg. [The Great War, the Civil War, and Recovery: Russia's National Income, 1913 to 1928]. Moscow, Mysl'. 111 p.

Maslov, E. (Ed.). (2017). 1917 god. Petrograd. Moskva. Bogorodsk. Khronika sobytii [1917. Petrograd. Moscow. Bogorodsk. Chronicle of Events]. Chernogolovka, Bogorodskii pechatnik. $122 \mathrm{p}$.

Medushevskii, A. N. (2017). Politicheskaya istoriya russkoi revolyutsii: normy, instituty, formy sotsial'noi mobilizatsii $v$ XX veke [The Political History of the Russian Revolution: Norms, Institutions, Forms of Social Mobilization in the $20^{\text {st }}$ Century]. Moscow, St Petersburg, Tsentr gumanitarnykh initsiativ. 656 p.

Mel'nikova, E. A. (2011). Ryad v Skazanii o prizvanii varyagov i ego evropeiskie i skandinavskie paralleli [A Contract in the Legend of the Calling of the Varangians and Its European and Scandinavian Parallels]. In Mel'nikova, E. A. Drevnyaya Rus'i Skandinaviya. Izbrannye trudy. Moscow, Russkii fond sodeistviya obrazovaniyu i nauke, pp. 249-256. 
Mel'nikova, E. A. (2017). Normannskaya problema [The Norman Problem]. In Drevnyaya Rus'v srednevekovom mire. Entsiklopediya. Moscow, Ladomir, pp. 560-561.

Mel'nikova, E. A. (Ed.). Slavyane i skandinavy [The Slavs and Scandinavians]. Moscow, Progress. 416 p.

Mel'nikova, E. A., Petrukhin, V. Ya. (1989). Nazvanie "Rus"” v etnokul'turnoi istorii Drevnerusskogo gosudarstva [The Name Rus' in Ethnic and Cultural History of the Early Russian State]. In Voprosy istorii. No. 8, pp. 24-38.

Mikhutina, I. V. (2007). Ukrainskii Brestskii mir. Put'vykhoda Rossii iz Pervoi mirovoi voiny $i$ anatomiya konflikta mezhdu Sovnarkomom RSFSR i pravitel'stvom Ukrainskoi Tsentral'noi rady [Ukrainian Brest Peace. Russia's Way out of the First World War and the Anatomy of the Conflict between the Council of People's Commissars of the RSFSR and the Government of the Ukrainian Central Rada]. Moscow, Evropa. 288 p.

Nevskaya, T. A., Kondrasheva, A. S. (2011). Vlast'i reformy na Severnom Kavkaze (konets XVIII - nachalo XX vv.) [Power and Reforms in the North Caucasus (Late $18^{\text {th }}-$ Early $20^{\text {th }}$ Centuries)]. Stavropol', Izdatel'stvo Severo-Kavkazskogo gosudarstvennogo tekhnicheskogo universiteta. $91 \mathrm{p}$.

Nikolaev, A. B. (Ed.). (2017). A. F. Kerenskii: pro et contra. Antologiya [A. F. Kerenskii: Pro et Contra. Anthology]. St Petersburg, Russkaya khristianskaya gumanitarnaya akademiya. $768 \mathrm{p}$.

Omurbekov, T. N., Chorotegin, T. K. (2005). Istoriya Kyrgyzstana (XIX v. - 1917 g.). Uchebnik dlya $8 \mathrm{kl}$. srednikh shkol [History of Kyrgyzstan (19 ${ }^{\text {th }}$ Century -1917$) .8^{\text {th }}$ Grade Textbook for Secondary Schools]. Bishkek, Biiiktik. 192 p.

Pashuto, V. T., Florya, B. N., Khoroshkevich, A. L. (1982). Drevnerusskoe nasledie $i$ istoricheskie sud'by vostochnogo slavyanstva [Old Russian Heritage and Historical Fate of the Eastern Slavs]. Moscow, Nauka. 264 p.

Pavlenko, S. (2005). Ivan Mazepa yak budivnichii ukrä̈ns'koï kul'turi [Ivan Mazepa as a Builder of Ukrainian Culture]. Kiev, Kiєvo-Mogilyans'ka akademiya. 304 p.

Pervaya mirovaya voina na pochtovykh otkrytkakh v $4 \mathrm{kn}$. [World War I on Postcards. 4 Books]. (2014). Kirov, Krepostnov". 1692 p.

Petrov, Yu. A., Pavlov, D. B. (2014). Pervaya mirovaya voina: kto vinovat? (Istoriograficheskii etyud) [World War I: Who is to Blame? (Historiographical Study)]. In Rossiiskaya istoriya. No. 5, pp. 3-13.

Petrov, Yu. A., Zhuravlev, S. V., Bakhturina, A. Yu. (2018). Prichiny, posledstviya i otsenka padeniya monarkhii $v$ Rossii, Revolyutsii 1917 g., prikhoda $k$ vlasti bol'shevikov $i$ ikh pobedy v Grazhdanskoi voine [Causes, Consequences and Assessment of the Fall of the Monarchy in Russia, the Revolution of 1917, the Coming to Power of the Bolsheviks and their Victory in the Civil War.]. In Elektronnyi nauchno-obrazovatel'nyi zhurnal "Istoriya" [website]. Trudnye voprosy istorii Rossii. URL: https://history.jes.su/s2079878400012829-1/ (mode of access: 22.04.2020). DOI 10.18254/S207987840001282-9.

Prokopov, T. F. (Ed.). (2017). Revolyutsiya glazami sovremennikov [The Revolution through the Eyes of Contemporaries]. Moscow, AST. 480 p.

Rakhimov, Zh. (2001). Istoriya Uzbekistana (vtoraya polovina XIX v. -nachalo XXv.). Uchebnik dlya 9-go klassa [The History of Uzbekistan (Second Half of the $19^{\text {th }}$ Century Beginning of the $20^{\text {th }}$ Century). Textbook for $9^{\text {th }}$ Grade]. Tashkent, Uzbekiston. $334 \mathrm{p}$.

Revolyutsiya 1917 goda glazami sovremennikov $v 3 t$. [The Revolution of 1917 through the Eyes of Contemporaries. 3 Vols.]. (2017). Moscow, ROSSPEN. 1608 p.

Reznik, A. V. (Ed.). (2016). L. D. Trotskii: pro et contra. Antologiya [L. D. Trotsky: Pro et Contra. Anthology]. St Petersburg, Russkaya khristianskaya gumanitarnaya akademiya. $864 \mathrm{p}$.

Rossiiskaya gazeta - Nedelya. Kirgiziya. No. 6975. 19 maya 2016 [Russian Gazette Week. Kyrgyzstan. No. 6975. May 19, 2016]. (2016). In Rossiiskaya gazeta [website]. URL: https://rg.ru/gazeta/nedelya-aziya/2016/05/19.html (mode of access: 20.12.2019).

Rossiiskaya revolyutsiya 1917 g. i ee mesto v istorii XX veka [The Russian Revolution of 1917 and its Place in the History of the $20^{\text {th }}$ century]. In Institut vseobshchei istorii Rossiiskoi akademii nauk [website]. URL: (mode of access: 20.12.2019). 
Rossiya - Bashkortostan: obshchnost' istoricheskikh sudeb [Russia - Bashkortostan: A Community of Historical Destinies]. In Elektronnyi nauchno-obrazovatel'nyi zhurnal "Istoriya" [website]. URL: https://history.jes.su/issue.2015.3.9.e5/ (mode of access: 20.12.2019).

Rossiya $i$ Pervaya mirovaya voina: ekonomicheskie problemy, obshchestvennye nastroeniya, mezhdunarodnye otnosheniya [Russia and the First World War: Economic Problems, Public Sentiment, International Relations]. (2014). Moscow, Institut rossiiskoi istorii RAN. 416 p.

Rossiya i Ukraina na perekrestkakh istorii. Posobie dlya uchitelei istorii [Russia and Ukraine at the Crossroads of History. A Manual for History Teachers]. (2012). Moscow, OLMA Media Group. 320 p.

Rossiya $v$ sisteme mezhdunarodnykh otnoshenii nakanune $i v$ gody Pervoi mirovoi voiny $v 3 t$. [Russia in the System of International Relations on the Eve of and During the First World War. In 3 Vols.]. (2019). Moscow, Mezhdunarodnye otnosheniya. 1368 p.

Rybakov, B. A. (1982). Kievskaya Rus'i russkie knyazhestva XII-XIII vv. [Kievan Rus and Russian Principalities of the $12^{\text {th }}-13^{\text {th }}$ Centuries]. Moscow, Nauka. 592 p.

Sakharov, A. N. (2003). Ryurik, varyagi i sud'by rossiiskoi gosudarstvennosti [Rurik, the Vikings and the Fate of Russian Statehood]. In Sbornik Russkogo istoricheskogo obshchestva. No. 8 (156), pp. 9-17.

Shteinberg, I. Z. (2017). Nravstvennyi lik revolyutsii [The Moral Face of the Revolution]. Moscow, Kuchkovo pole. 416 p.

Shubin, A. V. (2017a). Velikaya rossiiskaya revolyutsiya. 10 voprosov [The Great Russian Revolution. 10 Questions]. Moscow, Istoriya. 46 p.

Shubin, A. V. (2017b). Start Strany Sovetov. Revolyutsiya. Oktyabr'1917-mart 1918 [Start of the Country of Soviets. Revolution. October 1917 - March 1918.]. St Petersburg, Piter. $448 \mathrm{p}$.

Sitii, I. (Ed.). (2005). Mazepina kniga [Book of Mazepa]. Chernihiv, Tsentr naukovotekhnichnoï i ekonomichnoï informatsiï. $524 \mathrm{p}$.

Skocpol, T. (2017). Gosudarstva i sotsial'nye revolyutsii: sravnitel'nyi analiz Frantsii, Rossii i Kitaya [States and Social Revolutions: A Comparative Analysis of France, Russia, and China]. Moscow, Izdatel'stvo Instituta Gaidara. $550 \mathrm{p}$.

Smolii, V. A. (Ed.). (2008). Istoriya Ukrainy: nauchno-populyarnye ocherki [History of Ukraine: General Audience Essays]. Moscow, OLMA Media Group. 1070 p.

Soldatenko, V. F. (1999). Ukraïns'ka revolyutsiya. Istorichnii naris [The Ukrainian Revolution. A Historical Essay]. Kiev, Libid'. 976 p.

Somov, K. A. (2017). Dnevnik. 1917-1923 [Diary. 1917-1923]. Moscow, Dmitrii Sechin. $928 \mathrm{p}$.

Sorokin, A. K. (Ed.). (2017). Rossiya v 1917 godu. Entsiklopediya [Russia in 1917. Encyclopedia]. Moscow, ROSSPEN. 1095 p.

Sovetskie natsii $i$ natsional'naya politika v 1920-1950-e gody. Materialy VI Mezhdunarodnoi nauchnoi konferentsii, Kiev, 10-12 oktyabrya 2013 g. [Soviet Nations and National Politics in the 1920-1950s. Materials of the $6^{\text {th }}$ International Scholary Conference, Kiev, October 10-12, 2013]. (2014). Moscow, Politicheskaya entsiklopediya, Fond "Prezidentskii tsentr B. N. El'tsina". 686 p.

Stanislavs'kii, V. (Ed.). (2002). Listi Ivana Mazepi v 2 t. [Letters from Ivan Mazepa. 2 Vols.]. Kiev, Institut istorii Ukraïny Natsional'noi akademii nauk Ukraïny. Vol. 1. 16871691. 480 p. Vol. 2. 1691-1700. 752 p.

Strukevich, O. K. (2017). Istoriya Ukraïni: pidruchnik dlya 9 klasu zagal'noosvitnikh navchal'nikh zakladiv [History of Ukraine. $9^{\text {th }}$ Grade Textbook for General Education Schools]. Kiev, Gramota. 240 p.

"Svet vo t'me...". V bor'be za Rossiyu. 1917-1922 ["Light in the darkness...". In the Fight for Russia. 1917-1922]. (2017). Moscow, Posev. 305 p.

Taïrova-Yakovleva, T. G. (2013). Ivan Mazepa i Rosiis'ka imperiya. Istoriya "zradi" [Ivan Mazepa and the Russian Empire. The Story of "Betrayal"]. Kiev, Klio. 403 p. 
Torkunov, A. V., Chubar'yan, A. O. (Eds.). (2018). Rossiiskaya revolyutsiya 1917 goda i ee mesto v istorii XX veka [The Russian Revolution of 1917 and Its Place in the History of the $20^{\text {th }}$ Century]. Moscow, Ves' mir. $352 \mathrm{p}$.

Trotsky, L. D. (2017a). Istoriya russkoi revolyutsii. Oktyabr'skaya revolyutsiya [The History of the Russian Revolution. October Revolution]. Moscow, Veche. 416 p.

Trotsky, L. D. (2017b). Istoriya russkoi revolyutsii. Fevral'skaya revolyutsiya [The History of the Russian Revolution. February Revolution]. Moscow, Veche. 448 p.

Vlasov, V. S. (2016). Istoriya Ukraïni. Pidruchnik dlya 8-go klasu zagal'noosvitnikh navchal'nikh zakladiv [History of Ukraine. $8^{\text {th }}$ Grade Textbook]. Kiev, Geneza. 256 p.

Voina i islam na Severnom Kavkaze XIX-XX vv. [War and Islam in the North Caucasus of the $19^{\text {th }}-20^{\text {th }}$ Centuries]. (2000). Moscow, Institut rossiiskoi istorii RAN. 54 p.

Voina i obshchestvo $v X X v \vee v 3 \mathrm{kn}$. [War and Society in the $20^{\text {th }}$ Century. 3 Books]. (2008). Moscow, Nauka. Book 1. Voina i obshchestvo nakanune i v period Pervoi mirovoi voiny. $611 \mathrm{p}$.

Vosstanie 1916 goda v Turkestane: dokumental'nye svidetel'stva obshchei tragedii. Sbornik dokumentov $i$ materialov [The Uprising of 1916 in Turkestan: Documentary Evidence of a General Tragedy. Collection of Documents and Materials]. (2016). Moscow, Mardzhani. 468 p.

Z epistolyarnoï spadshchini get'mana Ivana Mazepi [From the Epistolary Heritage of Hetman Ivan Mazepa]. (1996). Kiev, Institut istorii Ukraïny Natsional'noi akademii nauk Ukraïny. $191 \mathrm{p}$.

Zimin, A. A. (1974). O metodike izucheniya drevnerusskogo letopisaniya [About the Methodology for Studying Old Russian Chronicles]. In Izvestiya Akademii nauk SSSR. Seriya Literatura i yazyk. Vol. 33. No. 5, pp. 454-464.

The article was submitted on 21.12.2019 